\title{
PENINGKATAN MUTU PENDIDIKAN PEMBELAJARAN BAHASA INDONESIA MELALUI PROGRAM PENUGASAN DOSEN DI SEKOLAH DASAR NEGERI 04 KOTABUMI LAMPUNG
}

\author{
Nur Mei Ningsih *) \\ nurmeiningsih02@gmail.com
}

\author{
Pendidikan Bahasa dan Sastra Indonesia \\ STKIP Muhammadiyah Kotabumi
}

\begin{abstract}
The improvment of education in Indonesia should be done soon, because the quality of education in Indonesia is lower than others. To improve the quality of Indonesian teacher is by improving the collaboration of teacher competence by Training Lecturer Program at School. This activity will bring the positif effect to high school and the aim school. This program needs lecturer's commitment to be a teacher in aim school. This activity becomes a new experience and it's not easy to be done by a lecturer. The lecturer has a new habit there because it is different from their usuall habit. The purposes of Training Lecturer Program at School (1) giving a new experience in uderstanding and developing the students' character, managing the activity of learning at school, and comprehending daily experience and sociocultural of society: (2) producting the device of collaborative learning between lecturer and teacher at aim school; (3) creating the quality of learning by making good atmosphere, the quality of device learning, and improving the successful of students; (4) improvement the relationship between high school with the aim school in all forms of the quality of learning. By Training Lecturer Program at School, it hopes could improve the quality of education.
\end{abstract}

\section{Keywords: Improvement of Education, Language Learning, PDS}

\section{PENDAHULUAN}

Kedudukan pembelajaran dalam pembelajaran Abad 21 juga digambarkan dalam sistem yang dikembangkan. Dalam pembelajaran Abad 21 menurut kerangka pembelajaan, elemen-elemen saling mendukung (standar dan penilaian, kurikulum dan pelajaran, dan lingkungan belajar) harus mampu membantu pembelajar mencapai kompetensi. Unsur utama pendidikan adalah guru dan dosen, dalam pembelajaran. Dalam proses pembelajaran tentunya melibatkan dua unsur yang tidak terpisahkan yaitu antara pendidik/pengajar dan pembelajar/peserta didik (Priyatni .2014:270). Untuk mewujudkan pendidikan yang bermutu, maka diperlukan juga guru yang bermutu, dosen yang bermutu atau sumber daya yang memiliki kompetensi dibidangnya, sehingga proses pembelajaran yang 
dilaksanakan akan semakin baik, hal ini dapat dilakukan melalui kolaboratif atau kerja sama antara dosen dan guru dalam melaksanakan pembelajaran di sekolah. Banyaknya tuntutan untuk terus memperbaiki kualitas, kompetensi, serta membangun citra terbaik bagi guru dan dosen. Peningkatan mutu pendidikan di Indonesia pun harus segera dilaksanakan, hal ini dikarenakan masih rendahnya kualitas pendidikan Indonesia dibanding dengan negara lain. Kementerian Pendidikan dan Kebudayaan (Kemendikbud) giat memacu kinerjanya untuk meningkatan citra terbaik bagi mutu guru di Indonesia. Salah satunya adalah melalui pemberdayaan peningkatan kompetensi guru melalui kolaboratif dengan pihak lain yakni dengan dosen melalui Program Penugasan Dosen di Sekolah.

Upaya peningkatan mutu pendidikan melalui perbaikan proses pembelajaran merupakan inovasi yang terus dilakukan. Salah satu inovasi tersebut adalah mengubah paradigma pembelajaran dari pembelajaran yang berpusat pada guru/dosen menjadi pembelajaran yang berpusat pada pembelajar/peserta didik. Pada kenyataanya pendekatan pembelajaran yang dilakukan selama ini lebih banyak berpusat pada guru/dosen atau berbasis mengajar, artinya bahwa selama proses pembelajaran guru/dosen lebih banyak memberi materi yang berupa pengetahuan. Pembelajar/peserta didik diharapkan dapat menguasai konsep/pengetahuan yang diberikan oleh pengajar/dosen dalam pembelajaran. Guru/Dosen lebih banyak mendominasi pembicaraan, sementara pembelajar/peserta didik hanya sebagai wadah yang akan diberi informasi pengetahuan, tanpa memberikan hakhaknya kepada pembelajar/peserta didik sebagai pembelajar. Berbeda pada kondisi sekarang ini pembelajaran tidak lagi bersifat konvensional yang lebih menekankan pada pengajarnya, tetapi diubah menjadi berpusat pada pembelajar/peserta didik atau berbasis belajar. Adapun ciri utama dalam pembelajaran berbasis belajar supaya terbangunnya kemandirian untuk membangun pengetahuan dan ketrampilan di dalam dirinya sendiri dari berbagai variasi informasi melalui interaksi dalam pembelajaran. Selain membangun pengetahuan dan keterampilan, pengembangan sikap sangat diutamakan, supaya pembelajar/peserta didik berkarakter lebih baik lagi.Pengembanganpengembangan tersebut dapat dilakukan melalui kolaboratif antara guru dengan dosen di sekolah. Kolaboratif yang dilakukan melalui Program Penugasan Dosen di sekolah atau PDS.

Kegiatan Penugasan Dosen di Sekolah merupakan kegiatan yang 
memberikan dampak positif baik bagi perguruan tinggi maupun bagi pihak sekolah mitra. Program Penugasan Dosen di Sekolah membutuhkan komitmen dosen untuk mengalami dan menjadi guru di sekolah mitra. Menjadi guru di sekolah bagi seorang dosen adalah hal baru dan tidak mudah untuk dilakukan. Dosen perlu menyesuaikan dengan berbagai hal yang biasa berlaku di sekolah. Dosen yang bertugas di sekolah dapat menyesuaikan dengan lingkungan sekolah yang sangat berbeda dengan tempat tugasnya di perguruan tinggi.. Kegiatan Penugasan Dosen di sekolah bermitra dengan Sekolah Dasar Negeri 04 Kotabumi. Guru mitra bernama Dewi Adykarini yang menjadi guru kelas VI di sekolah mitra tersebut

Program Penugasan Dosen di Sekolah mengandung multifungsi dalam peningkatan kualitas guru yang profesional. Lembaga Pendidikan Tinggi ke sekolah mitra terkait dengan pesatnya perkembangan ilmu pendidikan dan teoriteori belajar, memfasilitasi dosen untuk menghayati secara langsung menjadi "guru" di sekolah mitra. "program ini dapat memperkokoh kemitraan antara Lembaga Pendidikan Tinggi dan sekolah mitra, yang muaranya untuk meningkatkan kualitas pembelajar/peserta didik dalam memeroleh pengetahuan dan pengalaman belajar.

Kegiatan Penugasan Dosen di Sekolah (PDS) bertujuan (1) memberikan pengalaman bagi para dosen perguruan tinggi dalam memahami perkembangan dan karakteristik siswa, mengelola kegiatan pembelajaran yang mendidik di sekolah, dan menghayati pengalaman keseharian dan nuansa sosio-kultural sekolah; menghasilkan perangkat pembelajaran kolaboratif antara dosen perguruan tinggi dengan guru sekolah mitra; (3) menciptakan pembelajaran yang bermutu dengan indikator terciptanya iklim pembelajaran yang semakin baik, perangkat pembelajaran yang semakin berkualitas, dan meningkatnya prestasi belajar siswa; (4) Menguatkan hubungan kemitraan antara Lembaga Pendidikan Tinggi dengan sekolah mitra dalam berbagai bentuk program peningkatan kualitas pembelajaran dan pelaksanaan.

Kegiatan Program Penugasan Dosen di Sekolah bermitra dengan Sedolah Dasar Negeri 04 untuk menciptakan pembelajaran yang bermutu. Artinya dalam proses pembelajaran memerlukan tenaga yang unggul dan professional dalam bidangnya. Kolaboratif yang dimaksudkan untk meningkatkan mutu pendidikan yang ada pada Satuan Pendidikan. Upaya perbaikan pembelajaran bukan hanya melihat dari sisi pembelajar/peserta didik saja tetapi juga mengupayakan supaya guru/dosen dapat meningkatkan kualitas dalam pembelajaran. Salah satu model pembinaan dan pengembangan untuk meningkatkan 
kualitas tenaga pengajar/dosen adalah melalui model lesson study.

\section{METODE}

Metode yang digunakan adalah metode kualitatif dalam latar yang wajar (natural) dengan berupaya memahami dari apa yang diamati (Santana.2010:45). Metode ini juga disebut metode artistic (Sugiyono.2011:7) karena proses bersifat seni (kurang terpola) dan disebut metode interpretative karena hasil berkenaan dengan interpretasi data yang dikumpulkan di lapangan. Metode yang digunakan dalam penyusunan artikel berdasarkan pengamatan langsung terhadap pembelajaran yang dilaksanakan oleh dosen berkolaborasi dengan guru kelas dalam pelaksanaan pembelajaran Bahasa Indonesia (Tematik). Dosen mendeskripksikan mengenai pelaksanaan pembelajaran yang dilaksanakan pada Siswa Sekolah Dasar 04 Kotabumi Lampung Utara.

\section{HASIL DAN PEMBAHASAN}

Berdasarkan hasil pembelajaran yang dilaksanakan di SD Negeri 04 Kotabumi dosen berkolaborasi dengan guru kelas melaksanakan pembelajaran Bahasa Indonesia (tematik) menggunakan kegiatan Lesson study. Menurut Hendayana, (2007:10) Lesson study merupakan model pembinaan profesi pendidik melalui pengkajian pembelajaran secara kolaboratif dan berkelanjutan berlandaskan prinsipprinsip kolegalitas dan mutual learning untuk membangun komunitas belajar. Lesson study bukan merupakan metode atau strategi pembelajaran tetapi merupakan suatu kegiatan. Lesson study dapat menerapkan berbagai metode ataupun strategi pembelajaran yang sesuai dengan situasi, kondisi, dan permasalahan yang dihadapi pendidik. Lewis dan Murata (2006) dalam Susilo (2011:3) dalam melaksanakan Lesson study pengajar/dosen secara kolaboratif (1) mempelajari kurikulum dan merumuskan tujuan pembelajaran dan tujuan pengembangan peserta didiknya (mengembangkan kecakapan hidupnya, (2) merancang pembelajaran untuk mencapai tujuan,( 3) melaksanakan dan mengamati suatu research lesson dan, (4) melakukan refleksi untuk mendiskusikan pembelajaran berikutnya. Menurut Slamet dan khotimah (2010:59) Lesson Study merupakan kegiatan terus menerus yang tiada henti dan suatu upaya untuk mengaplikasikan prinsipprinsip dalam Total Quality Management, yakni memperbaiki proses dan hasil pembelajaran siswa secara terus-menerus, berdasarkan data. Lesson Study merupakan model pembinaan profesi pendidik melalui pengajian pembelajaran secara kolaboratif dan berkelanjutan berlandaskan azas-azas kolegalitas dan mutual learning untuk 
membangun komunitas belajar (Sumardi Y, 208:58). lesson study adalah suatu pendekatan peningkatan kualitas pembelajaran yang dilaksanakan oleh dosen secara kolaboratif, dengan langkah-langkah pokok merancang pembelajaran untuk mencapai tujuan, melaksanakan pembelajaran, mengamati pelaksanaan pembelajaran, serta melakukan refleksi untuk mendiskusikan pembelajaran yang dikaji untuk bahan penyempurnaan dalam rancangan pembelajaran pada tahap berikutnya.

$\mathrm{h}$ ttp//akhmadsudrajad.wordpress com/2008/02/22/lessonstudy-untuk meningkatkan-pembelajaran

Sukirman (2006:32) memandang lesson study sebagai model pembinaan profesi pendidik melalui pengka jian pembelajaran secara kolaboratif dan berkelanjutan berdasarkan prinsip-prinsip kolegalitas mutual learning untuk membangun learning community. Dengan demikian lesson study bukan suatu metode pembelajaran atau strategi pembelajaran. Namun demikian dalam suatu kegiatan lesson study dapat digunakan berbagai metode, pendekatan, strategi pembelajaran sesui dengan situasi dan kondisi dan permasalahan yang dihadapi. Melalui pembinaan profesi ini pengajar/dosen dapat meningkatkan kualitas dalam pembelajaran terutama dalam pembelajaran mata pelajaran Bahasa Indonesia (tematik) (Pelatihan PEKERTI 2017).

Tahap pembelajaran yang dilaksanakan di SD Negeri 04 pada mata pelajaran Bahasa Indonesia kelas VI dilaksanakan dalam tiga tahapan yang mencakup plan (merencanakan), Do (melaksanakan), dan See (refleksi)sebagai berikut.

\section{Plan (Merencanakan)}

Tahap perencanaan (Plan), pada tahap perencanaan ini dosen bersama guru secara kolaboratif menyusun Perangkat Pembelajaran mata pelajaran Bahasa Indonesia. Tahap perencanaan ini,dosen bersama guru merancang mengenai materi ajar, metode, pendekatan, instrument penilaian serta strategi atau model pembelajaran yang sesuai dengan karateristik siswa di sekolah untuk menghasilkan skenario pembelajaran yang baik dan tepat secara operasional (sesuai dengan kondisi dan sistuasi peserta didik serta sarana pendukungnya). Perencanaan pembelajaran yang disusun dilakukan secara kolaboratif berdasarkan permasalahan di kelas untuk mengembangan model pembelajaran yang berpusat pada peserta didik. Rencana Pelaksanaan Pembelajaran atau RPP disesuaikan dengan kurikulum yang ditetapkan pada satuan pendidikan atau sekolah tersebut. Rencana Pelaksanaan Pembelajaran yang disusun untuk dua 
Kompetensi Dasar dengan tema/materi pokok: Persatuan dalam Perbedaan (a) Peristiwa Penting Menjelang Kemerdekaan; (b) Proklamasi Kemedekaan Indonesia; (c) Peristiwa Penting Menjelang Proklamasi Kemerdekaan; serta (d) Pengibar Sangsaka Merah Putih. Dari materi pokok tersebut dilaksanakan selama delapan kali dengan durasi waktu 2x35 menit untuk seiap kali pertemuan. Rencana dalam pelaksanaan pembelajaran menggunakan pendekatan saintifik/model pembeajaran (snowball trowing, membaca dan menulis, kontekstual, supaya pembelajaran jadi bermakna untuk peserta didik tersebut. Langkah-langkah yang akan dilakukan oleh peserta didik dalam mata pelajaran Bahasa Indonesia dengan adalah (1) peserta didik membentuk kelompok 4-5 orang; (2) membaca materi sesuai dengan tema (3) peserta didik menyusun/ membuat pertanyaan; (4) peserta didik menggulung kertas/membuat seperti bola yang berisi pertanyaan, lalu dilemparkan kepada kelompok lain; (5 ) peserta didik yang mendapatkan gulungan kertas/membuat seperti bola yang berisi pertanyaan, maka kelompok tersebut yang harus menjawab pertanyaan secara bergantian; (6) peserta didik diminta untuk menyimpulkan secara sederhana inti materi yang didiskusikan. Begitu pula dengan model pembelajaran yang lainnya yang digunakan dalam melaksanakan pembelajaran. Hal ini disesuaikan dengan karakteristik peserta didiknya.

\section{Pelaksanaan (Do)}

Tahap pelaksanaan (Do), dosen berkolaboratif dengan guru kelas menerapkan rancangan pembelajaran yang sudah disusun atau dibuat dalam pembelajaran. Dalam tahap Do seorang “dosen bersama guru " melakukan pembelajaran di kelas. Dosen mengawali dengan memaparkan langkah-langkah yang harus dilakukan oleh peserta didik selama mengikuti proses pembelajaran. Adapun langkah-langkah yang dilaksanakan selama proses pembelajaran mata pelajaran Bahasa Indonesia,

a. dosen menjelaskan materi yang akan dibahas dalam pembelajaran;

b. dosen membagi kelompok dan mengelompokan peserta didik;

c. peserta didik mendiskusikan secara kelompok materi yang dibahas;

d. peserta didik menyusun pertanyaan dan mengembangkan peta pikiran;

e. peserta didik mengemukakan hasil diskusi;

f. peserta didik lain mengajukan pertanyaan dan siswa lain menjawab pertanyaan;

g. menyimpulkan secara sederhana materi yang dibahas;

h. dosen dan guru menegaskan kembali materi yang dibahas dan 
menyimpulkan inti materi sesuai dengan materi tersebut.

Dalam proses pembelajaran yang dilaksanakan pada pertemuan pertama tanggal 18 Agustus 2018 Pukul 7.15 wib diawali dengan perkenalan dosen dan peserta didik, kemudian dilanjutkan dengan penjelasan materi tema Persatuan dalam Perbedaan dengan teks/naskah yang berjudul "Peristiwa Penting Menjelang Kemerdekaan"

Dosen memaparkan/menjelaskan mengenai materi yang akan dibahas sesuai dengan yang ditetapkan dalam kurikulum. Materi yang dijelaskan kemudian ditanyakan kembali oleh dosen kepada peserta didik untuk mengetahui penguasaan pengetahuan yang didapat setelah peserta didik mendengarkan penjelasan dari dosen. Dosen meminta peserta didik untuk berkelompok mendiskusikan materi yang baru asaja dijelaskan, peserta didik mendiskusikan materi secara kelompok. Dalam diskusi peserta didik menuliskan peta pikiran dan mengembangkannya berdasarkan peta pikiran yang sudah dibuat oleh peserta didik dalam kelompoknya, pesersatuan dengan yang lainnya saling bekerja sama dalam membuat peta pikiran dan mengembangkanya sesuai dengan tema yang dibahas. Dalam kegiatan diskusi yang dilaksanakan ternyata ada satu kelompok peserta didik yang kurang aktif, hal ini dikarenakan peserta didik tidak membawa buku pelajaran (Tematik), sehingga kesulitan untuk mengerjakan dan mendiskusikan materi yang dibahas.

Pada pertemuan Senin, 20 Agustus 2018, dosen berkolaboratif dengan guru kelas melaksanakan proses pembelajaran dengan tema Persatuan dalam Perbedaan dan materi teks" Proklamasi Kemerdekaan Indonesi" pada proses pembelajaran dosen memaparkan langkah-langkah yang harus dilakukan dalam pembelajaran: a) Siswa diminta untuk mengamati gambar tulisan asli dari teks proklamasi selama satu menit, b) Kemudian, setiap siswa menjawab pertanyaan dan menukarkannya dengan teman di sebelahnya dan mendiskusikan jawabannya, c) Dosen dan Guru membimbing diskusi, berjalan berkeliling dari kelompok satu ke kelompok lain untuk memastikan bahwa setiap anggota berpartisipasi secara aktif dalam mengikuti kegiatan diskusi. d) Guru dan dosen sambil berkeliling meminta satu siswa untuk menyampaikan hasil diskusinya. Kemudian, memberi penguatan kepada seluruh siswa mengenai jawaban yang diharapkan. Guru dapat memberi kesempatan kepada seluruh siswa untuk memberikan komentar dari jawaban yang ada. Guru dapat menguatkan jawaban-jawaban yang ada, e) Siswa kemudian membaca teks tentang" Proklamasi Kemerdekaan Indonesia" dan mengisi peta pikiran, f) Bersama temannya, 
siswa mendiskusikan peta pikiran masingmasing. Guru berkeliling untuk memastikan semua siswa aktif dalam mengikuti diskusi. Proses pembelajaran yang berlangsung peserta didik termotivasi dan aktif dalam mengikuti pembelajaran, bahkan peserta didik dalam kelompok memberitahu atau mengajari peserta didik yang belum paham mengenai materi yang didiskusikan. Pembelajaran yang dilaksnakan bukan saja transaksi tetapi terjadi interaksi antara dosen/guru dan peserta didik, antarpeserta didik dengan peserta didik lainnya dalam kelompok, dan peserta dalam kelompok dengan kelompok lainnya.Melalui kegiatan inilah pembelajaran menjadi bermakan untuk peserta diddik.

Pada pertemuan selanjutnya yang dilaksanakan tanggal 25 Agustus 2018 dengan Persatuan dalam Perbedaan dengan tek "Proklamasi Kemerdekaan Indonesia" Di awal proses pembelajaran Guru dan dosen mengemukakan langkah-langkah yang harus dilakukan oleh siswa dan dosen dalam kelas. Dosen menjelaskan bagaiman cara mencari informasi penting yang ada dalam teks dengan memberikan contoh kalimat Tanya yang ada dalam teks. Lalu siswa diminta untuk menemukan sendiri informasi penting melalui teks yang diberikan.Siswa secara kelompok mengambil kartu yang berisi pertanyaan dan kartu yang lain berisi jawaban. Siswa diminta untuk memilih kartu dan yang mendapat kartu tersebut bagi kelompok lain memberikan jawaban sesuai pertanyaan.Pembelajaran yang dilaksnakan dalam bentuk permainan yakni permainan dengan menggunakan kartu yang berisi pertanyaan dan kartu yang berisi jawaban. Masing-masing kelompok mendapatkan kartu yang berisi pertanyaan dan berisi jawaban.Disinilah peserta didik belajar sambil bermain, permainan yang mengolah pola pikir anak dan cermat menangapi pertanyaan yang ada dalam setiap kartu guna menemukan dan mengemukakan jawaban sesuai dengan kartu yang didapat. Peserta didik sangat aktif dan antusias mengikuti pembelajaran.

Pada pertemuan tanggal 29 Agustus 2018 dengan teks "Peristiwa Penting Menjelang Proklamasi Kemerdekaan" diawali dengan Langkah kegiatan pembelajaran a) Guru mendampingi dosen pada saat dosen menunjukkan gambar Soekarno sedang membaca teks proklamasi dan mengajak siswa untuk bercurah pendapat, lalu Ceritakan tentang gambar yang sedang kalian amati, b) Dosen kemudian menyampaikan informasi kepada siswa bahwa hari ini mereka akan membaca teks tentang Peristiwa Penting Menjelang Proklamasi Kemerdekaan, c) guru mengarahkan siswa untukn melanjutkan kegiatan dengan membaca teks dan mengisi peta pikiran, d) guru membimbing siswa dalam kelompok untuk menyampaikan peta 
pikiran, f) Dosen meminta salah seorang siswa untuk membacakan peta pikirannya di depan kelas dan memberikan masukan, kemudian guru membimbingnya. Sedangkan siswa lain diberi kesempatan untuk berkomentar, g) Guru dan dosen memberikan penguatan, h) Setiap siswa kemudian mengembangkan peta pikirannya dan membacakannya di depan kelas.

Pada pertemuan 3 September 2018 membahas teks "Pengibar Sangsaka Merah Putih". Dosen dan guru meniawali pembelajaran dengan langkah kegiatan a) Siswa melanjutkan kegiatan dengan membaca teks yang ada pada buku pelajaran. Siswa membaca teks dalam hati. Guru memberikan waktu sekitar 2 menit Literasi, b) Dosen dan guru berkeliling untuk memberikan bantuan saat siswa berdiskusi. Guru dan dosen bisa memberikan pertanyaan pancingan apabila diskusi tidak berjalan lancer, c) Siswa melanjutkan kegiatan dengan menemukan informasi penting dan mengisinya pada peta pikiran, d) Di dalam kelompoknya, siswa menyampaikan peta pikirannya, e) Dosen pendamping meminta salah satu siswa untuk membacakan peta pikirannya di depan kelas dan memberikan masukan. Siswa lain diberi kesempatan untuk berkomentar. Guru memberikan penguatan, f) Setiap siswa kemudian mengembangkan peta pikirannya dan membacakannya di depan kelas.

\section{Refleksi (See)}

Kegiatan refleksi dilakukan setelah kegiatan pembelajaran (do) selesai dilaksanakan, dosen bersama guru kelas melakukan sharing atau diskusi sederhana atas temuan yang terjadi dalam pembelajaran. Berdasarkan hasil temuan yang dilaksanakan dalam pembelajaran mata pelajaran Bahasa indonesia, dosen bersama guru melaksanakan perbaikan pembelajaran guna peningkatan kinerja dan perbaikan mutu pembelajaran yang dilaksnakan di sekolah tersebut.

\section{PENUTUP}

\subsection{Simpulan}

Komunitas belajar atau proses pembelajaran yang dilaksanakan oleh dosen berkolaboratif dengan guru pada siswa SD Negeri 04 Kotabumi mata pelajaran Bahasa Indonesia sangat baik. Hal ini terlihat melalui melalui kegiatan diskusi yang dilakukan peserta diik secara kelompok. Hasil menunjukan bahwa peserta didik sangat aktif dan antusias mengikuti pembelajaran karena menggunakan model pembelajaran dalam bentuk permainan, sehingga mempermudah peserta didik untuk menyerap dan memahami pengetahuan yang didapat, serta terampil untuk menerapkan dan mengerjakannya. Selain itu juga peserta didik juga mampu mengembangkan sikap berkarakter menjadi 
untuk menjadi lebih baik lagi.Melalui kegiatan ini pembelajaran menjadi lebih bermakana, karena hal ini disesuaikan dengan kehidupan serta pengalaman diperoleh sesuai dengan lingkunganya.

\subsection{Saran}

1. Dosen dapat meningkatkan motivasi untuk memperbaiki kinerja mengajarnya
2. Dosen dapat lebih memahami kondisi dan situasi pembelajaran di kelas.

3. Dosen dapat meningkatkan aktivitas pembelajaran di kelas.

4. Mahasiswa dapat meningkatkan kualitas cara belajar yang maksimal dan meningkatkan hubungan kerjasama antarmahasiswa dalam kelompok

\section{DAFTAR PUSTAKA}

Hendayana, dkk. 2007. Lesson Study Suatu Strategi Untuk Meningkatakan Keprofesionalan Pendidik (Pengalaman IMSTEP-JICA). Bandung: UPI Press http//akhmadsudrajad.wordpress com/2008/02/22/lesson study-untuk meningkatkanpembelajaran

Makalah Lesson Study disampaikan dalam Pelatihan Pengembangan Keterampilan Teknik Instruksional (PEKERTI). Universitas Muhammadiyah Metro selama 4-8 Januari 2017

Rusman.2010. Model-Model Pembelajaran Mengembangkan Profesional Guru. Bandung: Raja Grafinda Persada

Santanan K, Septiawan. 2010. Menulis Ilmiah Metodologi Penelitian Kualitatif Edisis Kedua. Jakarta: Yayasan Pustaka Obor Indonesia

Sukirman.2006.Peningkatan Profesional Guru Melalui Lesson Study. Makalah disampaikan pada kegiatan Pelatihan 2 Hari untuk Fasilitator dan Tim TPK SISTTEM Bantul Emergency Program, 11-12 Agustus 2016

Slamet, Subad, T, Sutama, \& Khotimah,R.P.2010. Peningkatan Kompetensi Guru Sekolah Dasar Melalui Lesson Study. Jurnal Warta, Vol .13, No.1, 55 - 64

Sugiyono. 2011. Metode Penelitian Kuantitatif, Kualitataif, dan R\&D. Bandung: Alfabeta

Sumardi Y. 2008. Perangkat Pendukung dalam Pelaksanaan Lesson Study. Makalah Pelatihan Bagi Dosen UNY. 
Susilo, Herawati. 2011. Lesson Study Berbasis sekolah, Guru Konservatf Menuju Guru Inovatif. Malang: Bayu Media Publihing.

Tri Priyatni Endah.2014. Desain Pembelajaran Bahasa Indonesia dalam Kurikulum 2013. Cahaya Prima Sentosa: Jakarta. 